\title{
Pengaruh Edukasi Melalui Media Video Dan Leaflet Terhadap Perilaku Personal Hygiene Pada Masa Menstruasi Remaja Di SMPN 2 Toili Kec. Mailong Kab. Banggai
}

\author{
*Lisa Handayani ${ }^{1}$, Een Kurnaesih ${ }^{2}$, Sundari ${ }^{3}$ \\ ${ }^{1,2,3}$ Pascasarjana Universitas Muslim Indonesia \\ *Email: lisacece6@gmail.com
}

\begin{abstract}
Background: Personal hygiene behaviour is a knowledge, attitude and actions taken by person to improve the degree of health, maintain self-hygiene, increase self-confidence, create beauty, and prevent disease. Therefore, youth must be prepared for both knowledge, attitude and action toward achieving healthy reproduction. Methods: This type of research uses quantitative methods with Quasy research experiments. The research design used in this study is Nonequivalent Control Group Design. The population in this study is a total of 12-15 years old young women, 135 people and samples of 34 of the young women in SMPN 2 Toili. Results: Research shows that there is an influence between educational knowledge through video media and the leaflet of personal hygiene behavior during adolescence. The results showed an influence between educational attitudes through video media and the leaflet of personal hygiene behavior during adolescence. The results showed that there was an influence between educational action through video media and a leaflet on the behavior of personal hygiene in adolescent menstruation. With the education of students better understand how to maintain personal menstrual hygiene with a significant level of < 0.05. Conclusion: There is a change in understanding knowledge, attitudes and actions of students when given the understanding that the importance of self-hygiene during menstruation. knowledge, attitudes, and actions that are influential and significant to the behavior of personal hygiene during adolescence in SMPN 2 Toili Kec. Mailong District. Banggai.
\end{abstract}

Keywords: education, media, personal hygiene, menstrual period, teenagers. 


\begin{abstract}
ABSTRAK
Latar belakang: Perilaku personal hygiene adalah suatu pengetahuan, sikap dan tindakan yang dilakukan oleh seseorang untuk meningkatkan derajat kesehatan, memelihara kebersihan diri, meningkatkan rasa percaya diri, menciptakan keindahan, dan mencegah timbulnya penyakit. Oleh karena itu, remaja harus dipersiapkan baik pengetahuan, sikap maupun tindakannya ke arah pencapaian reproduksi yang sehat. Metode: Jenis penelitian ini menggunakan metode kuantitatif dengan penelitian Quasy Eksperimen. Desain penelitian yang digunakan dalam penelitian ini adalah Nonequivalent Control Group Design. Populasi dalam penelitian ini adalah seluruh remaja putri yang berumur 12-15 tahun, yaitu sebanyak 135 orang dan Sampel 34 orang sebagian remaja putri di SMPN 2 Toili. Hasil: Penelitian menunjukkan terdapat pengaruh antara pengetahuan edukasi melalui media video dan leaflet terhadap perilaku personal hygiene pada masa menstruasi remaja. Hasil penelitian menunjukkan terdapat pengaruh antara sikap edukasi melalui media video dan leaflet terhadap perilaku personal hygiene pada masa menstruasi remaja. Hasil penelitian menunjukkan terdapat pengaruh antara tindakan edukasi melalui media video dan leaflet terhadap perilaku personal hygiene pada masa menstruasi remaja. Dengan adanya edukasi siswi lebih memahami bagaimana cara menjaga personal hygiene menstruasi dengan tingkat signifikan <0,05. Kesimpulan: terjadi perubahan pemahaman pengetahuan, sikap maupun tindakan siswi ketika diberikan pemahaman bahwa pentingnya kebersihan diri pada saat menstruasi. Pengetahuan, sikap, dan tindakan berpengaruh dan signifikan terhadap perilaku personal hygiene pada masa menstruasi remaja di SMPN 2 Toili Kec. Mailong kab. Banggai.
\end{abstract}

Kata Kunci: Edukasi, Media, Personal Hygiene, Masa Menstruasi, Remaja.

\section{LATAR BELAKANG}

Saat ini Indonesia terjadi perubahan struktur piramida penduduk, pola yang muncul di Indonesia mirip dengan struktur piramida penduduk di Negara maju. Pola ini menggambarkan adanya pengecilan jumlah dan proporsi penduduk berusia anak tetapi diikuti dengan membengkaknya penduduk remaja (1).

Masa remaja berawal saat usia 12 sampai dengan 24 tahun World Health Organization (WHO). Peraturan Menteri Kesehatan Republik Indonesia Nomor 25 Tahun 2014 menjelaskan remaja adalah penduduk dalam rentang usia 10-18 tahun Adapun peristiwa tersebut yaitu munculnya beberapa ciri alat kelamin sekunder meliputi tumbuh suburnya rambut pada area kewanitaan dan bulu ketiak, lingkar pinggul melebar, mengalami menstruasi (2). Masa remaja merupakan masa transisi antara masa kanak-kanak dengan dewasa. Remaja pada tahap ini belum mencapai kematangan mental dan sosial sehingga remaja harus menghadapi banyak tekanan emosi dan sosial saling bertentangan (3).

Data Survei Kesehatan Reproduksi Remaja Indonesia (SKKRI) tahun 2007 menyatakan bahwa secara nasional remaja yang perilaku hygiene dengan benar sebesar 21,6\%. Hasil survei menunjukkan remaja yang terpapar 
informasi Pusat Informasi dan Konseling Remaja mencapai $28 \%$. Berarti hanya 28 dari 100 remaja yang akses dengan kegiatan informasi kesehatan reproduksi yang berkaitan dengan menstruasi (4).

Masa remaja adalah proses tumbuh menuju ke arah kematangan termasuk dalam kematangan mental, emosional, sosial, dan fisik. Masa ini ditandai dengan kematangan organ seksual dan mampu untuk bereproduksi, dimana salah satu tanda pubertas seorang perempuan adalah menstruasi pertama atau menarche (5).

Menstruasi merupakan salah satu komponen seseorang perempuan dalam melalui masa pubertas yang mana perempuan kebanyakan menghadapi keterbatasan sosial dan kepercayaan diri sehingga bisa berkontribusi pada kesehatan mental maupun fisik. Pada saat menstruasi, personal hygiene perlu diperhatikan karena bersangkutan dengan kejadian infeksi genitalia sebanyak $75 \%$ wanita di dunia menderita vaginitis sekurang-kurangnya sekali dalam seumur hidup dan $10 \%$ hingga 55\% (6).

Perumusan masalah dalam penelitian ini adalah, apakah terdapat pengaruh edukasi melalui media video dan leaflet terhadap perilaku personal hygiene pada masa menstruasi remaja? Secara umum penelitian ini ingin bertujuan untuk mengetahui pengaruh antara pengetahuan, sikap dan tindakan terhadap perilaku personal hygiene pada masa menstruasi remaja.

Hipotesis dalam penelitian ini adalah terdapat pengaruh edukasi melalui video dan leaflet terhadap perilaku personal hygiene pada masa menstruasi remaja.

Kebersihan alat kelamin harus lebih dijaga karena kuman mudah sekali masuk dan dapat menimbulkan infeksi saluran reproduksi. Hygiene pada saat menstruasi merupakan komponen personal hygiene yang memegang peranan penting dalam status perilaku kesehatan seseorang, termasuk menghindari adanya gangguan pada fungsi alat reproduksi.

Tingkat pengetahuan antara remaja putri satu dengan lain berbeda-beda, termasuk pengetahuan mengenai cara membersihkan genetalia saat menstruasi, sehingga akan mempengaruhi sikap dan tindakan menjaga kebersihan genetalia saat menstruasi (7).

Menstruasi sering membuat remaja cemas, was-was dan kurang percaya diri. Remaja putri pada umumnya belajar tentang menstruasi dari ibunya, tapi sayang tidak semua ibu memberikan informasi yang memadai kepada putrinya bahkan sebagian enggan membicarakan secara terbuka. Menghadapi hal ini menimbulkan kecemasan pada anak, bahkan sering tumbuh keyakinan bahwa menstruasi itu sesuatu yang tidak menyenangkan atau serius (8).

Informasi tentang menstruasi dan praktek hygiene menstruasi sangat penting bagi seorang remaja putri. Anak perempuan yang tidak diajari untuk menganggap menstruasi sebagai fungsi tubuh normal dapat mengalami rasa malu dan dapat menganggap bahwa hal tersebut adalah kotor sampai masa dewasa. Banyak cara yang dapat kita gunakan untuk mendapatkan informasi tentang menstruasi dan praktek hygiene pada saat menstruasi, salah satunya media edukasi. Adanya informasi yang diperoleh dari media edukasi maka sangat mempengaruhi praktik hygiene menstruasi (9).

Sementara itu pengaruh lingkungan dan kebiasaan dapat mempengaruhi sikap remaja putri terhadap pentingnya 
konsumsi makanan yang mengandung zat besi saat menstruasi, sehingga hal ini akan berdampak pada kesehatan remaja putri. Pengetahuan mempengaruhi sikap individu dalam mempersepsikan objek, dan dari hasil persepsi ini akan menumbuhkan pendapat atau keyakinan individu mengenai objek sikap bersifat positif atau negatif (10).

Pengetahuan yang rendah cenderung memiliki sikap dan tindakan yang kurang sesuai. Salah satu faktor yang mempengaruhi perilaku kesehatan remaja putri dalam menghadapi pubertas yaitu sumber informasi. Sumber informasi yang kurang menyebabkan pengetahuan yang rendah dan akan berdampak pada sikap dan tindakan remaja putri. Sehingga diperlukan sumber informasi melalui pendidikan kesehatan yang bersifat inovatif dan menarik. Selain pendidikan kesehatan yang adekuat, penatalaksaan yang langsung diperagakan dapat menambah pengetahuan yang akan mempengaruhi pada sikap, keyakinan, pemahaman dan informasi yang diperoleh (8).

Sikap remaja puteri dalam menjaga kebersihan diri saat menstruasi memerankan peranan penting. Banyak remaja melaporkan mengalami stres sebelum dan saat menstruasi baik fisik dan mental karena terjadi dismenorea saat menstruasi. Remaja puteri melaporkan mengalami stress 99,6\% sejak pertama kali menstruasi, gejala yang dialami antara lain keram, sakit pada pinggang dan rasa tidak nyaman pada area kewanitaan (3).

Perilaku personal hygiene adalah suatu pengetahuan, sikap dan tindakan yang dilakukan oleh seseorang untuk meningkatkan derajat kesehatan, memelihara kebersihan diri, meningkatkan rasa percaya diri, menciptakan keindahan, dan mencegah timbulnya penyakit. Personal hygiene genitalia merupakan pemeliharaan kebersihan dan kesehatan individu yang dilakukan dalam kehidupan sehari-hari sehingga terhindar dari gangguan alat reproduksi dan mendapatkan kesejahteraan fisik dan psikis serta meningkatkan derajat kesehatan. Hal tersebut dapat membatasi komunikasi antara orang tua dan remaja tentang hygiene menstruasi. Perilaku kebersihan saat menstruasi berhubungan erat dengan teman sebaya, ketersediaan fasilitas alat pembersih, sikap dan pengetahuan (11).

Kesehatan merupakan salah satu metode yang tepat untuk memberikan informasi kepada remaja. Perilaku yang didasari dengan pengetahuan, lebih tahan lama dibandingkan perilaku yang tidak didasari pengetahuan. Pendidikan kesehatan merupakan bagian dari hak reproduksi remaja untuk memiliki pengetahuan, kesadaran, sikap dan tindakan pada saat menstruasi (12).

Personal hygiene menstruasi pada remaja merupakan isu kritis sebagai determinan status kesehatan remaja yang akan berpengaruh dalam kehidupan masa tua. Buruknya Personal hygiene menstruasi berpengaruh besar terhadap morbiditas dan komplikasi. Oleh karena itu, remaja harus dipersiapkan baik pengetahuan, sikap maupun tindakannya ke arah pencapaian reproduksi yang sehat (13).

Perilaku hygienis merupakan tema penting yang perlu ditelaah secara mendalam. Berdasarkan kajian teoritis yang ada, salah satu upaya mengurangi gangguan pada saat menstruasi yaitu membiasakan diri dengan perilaku higienis, namun perilaku higienis pada saat menstruasi tidak akan terjadi begitu saja tetapi merupakan sebuah proses yang dipelajari karena individu 
mengerti dampak positif atau negatif suatu perilaku yang terkait dengan keadaan menstruasi (14).

\section{METODE}

Jenis penelitian yang dilakukan adalah kuantitatif dengan metode penelitian Quasy Eksperimen. Desain penelitian yang digunakan dalam penelitian ini adalah Nonequivalent Control Group Design, untuk melihat adanya hubungan pengaruh edukasi melalui media video dan leaflet terhadap perilaku personal hygiene pada masa menstruasi remaja.

Populasi dalam penelitian ini seluruh remaja puteri yang berusia 1215 tahun di SMPN 2 Toili sebanyak 135 orang dan sampel sebagian remaja puteri yang berusia 12-15 tahun di SMPN 2 toili sebanyak 34 orang Lokasi penelitian ini dilaksanakan di SMPN 2 Toili Kec. Mailong Kab. Banggai pada bulan Maret-April 2020.

Definisi operasional, Edukasi merupakan proses pembelajaran yang betujuan untuk mengembangkan pemahaman dan pengetahuan remaja putri dalam melakukan personal hygiene saat menstruasi yaitu dengan menggunakan leaflet dan video. Kriteria Objektif nilai posttest meningkat setelah melihat video dan dibagikan leaflet. Sedangkan faktor external yang mempengaruhi yaitu mendapat informasi dari orangtua. Instrumen yang digunakan yaitu kuesioner untuk melihat pengetahuan responden sebelum diberikan perlakuan.

Analisis data univariat dilakukan dari tiap variabel dari hasil penelitian berupa distribusi frekuensi dan presentase dari tiap variabel.

Analisis bivariat analisis bivariat yaitu analisis yang dilakukan terlebih dahulu menggunakan uji normalitas data. Dan data terdistribusi secara normal maka digunakan uji Independent Sampel $\mathrm{T}$ Test.

Metode estimasi untuk pengukuran Data yang telah terkumpul, kemudian ditabulasi dalam tabel sesuai dengan variabel yang hendak diukur. Analisa data dilakukan melalui tahap editing, koding, tabulasi dan uji statistik. Uji statistik yang digunakan adalah univariat dan bivariat dengan menggunakan jasa komputerisasi yakni Program Statistical Product and Service Solution (SPSS).

\section{HASIL}

Tabel 1. Distribusi Frekuensi Karakteristik Responden Siswi SMPN 2 Toili

\begin{tabular}{ccc}
\hline Karakteristik & $\mathbf{N}$ & $\mathbf{\%}$ \\
\hline Umur & & \\
\hline 12 Tahun & 3 & 8,8 \\
13 Tahun & 22 & 64,7 \\
14 Tahun & 9 & 26,5 \\
\hline Usia Pertama Kali & & \\
Haid & & \\
\hline 11 Tahun & 6 & 17,6 \\
12 Tahun & 23 & 67,6 \\
13 Tahun & 5 & 14,7 \\
\hline
\end{tabular}

Berdasarkan tabel 1 menunjukkan bahwa dari 34 orang siswi yang dijadikan sebagai sampel, kelompok umur dominan berumur 13 tahun 22 orang $(64,7 \%)$ dibandingkan umur 14 tahun sebanyak 9 orang $(26,5 \%)$ dan umur 12 tahun sebanyak 3 orang $(8,8 \%)$. Sedangkan umur pertama kali haid dominan berumur 12 tahun sebanyak 23 orang $(67,6 \%)$ dibandingkan umur 11 tahun sebanyak 6 orang $(17,6 \%)$ dan umur 13 tahun sebanyak 5 orang $(14,7 \%)$. 
JAHR, Vol. 1, No. 1 (2020)

Tabel 2. Distribusi Frekuensi Berdasarkan Analisis Univariat Di SMPN 2 Toili

\begin{tabular}{ccccccccc}
\hline \multirow{2}{*}{ Variabel } & \multicolumn{4}{c}{ Pretest } & \multicolumn{3}{c}{ Posttest } \\
\cline { 2 - 10 } & \multicolumn{2}{c}{ Baik } & \multicolumn{2}{c}{ Kurang } & \multicolumn{2}{c}{ Baik } & \multicolumn{2}{c}{ Kurang } \\
\cline { 2 - 10 } & $\mathbf{N}$ & $\mathbf{\%}$ & $\mathbf{N}$ & $\mathbf{\%}$ & $\mathbf{N}$ & $\mathbf{\%}$ & $\mathbf{N}$ & $\mathbf{\%}$ \\
\hline Pengetahuan & 12 & 35,3 & 22 & 64,7 & 25 & 73,5 & 9 & 26,5 \\
\hline Sikap & 13 & 38,2 & 21 & 61,8 & 22 & 64,7 & 12 & 35,3 \\
\hline Tindakan & 9 & 26,5 & 25 & 73,5 & 20 & 58,8 & 14 & 41,2 \\
\hline
\end{tabular}

Berdasarkan tabel 2 menunjukkan bahwa dari 34 orang yang dijadikan sebagai sampel, berpengetahuan baik sebelum dilakukan perlakuan 12 orang $(35,3 \%)$ dan 22 orang $(64,7 \%)$ berpengetahuan kurang. Sedangkan setelah dilakukan perlakuan berpengetahuan baik 25 orang $(73,5 \%)$ dan berpengetahuan kurang 9 orang $(26,5 \%)$. Untuk variabel sikap yang memiliki sikap positif sebelum

Tabel 3 Uji $\mathrm{T}$ Test Perubahan PretestPosttest Edukasi Melalui Media Video Dan Leaflet Terhadap Perilaku Personal Hygiene Pada Masa Menstruasi Remaja

\begin{tabular}{|c|c|c|c|c|}
\hline $\begin{array}{c}\text { Variabe } \\
l\end{array}$ & $\begin{array}{c}\text { Mea } \\
\mathbf{n}\end{array}$ & SD & SE & $\begin{array}{c}\text { Nilai } \\
p\end{array}$ \\
\hline \multicolumn{5}{|c|}{ Pengetahuan } \\
\hline \multirow[t]{2}{*}{ Pretest } & 20.91 & 3.60 & 0.61 & \\
\hline & & 4 & 8 & 0,00 \\
\hline \multirow[t]{2}{*}{ Postest } & 23.06 & 3.27 & 0.56 & 0 \\
\hline & & 5 & 2 & \\
\hline \multicolumn{5}{|c|}{ Sikap } \\
\hline \multirow[t]{2}{*}{ Pretest } & 32.62 & 6.26 & 1.07 & \\
\hline & & 7 & 5 & 0,00 \\
\hline \multirow[t]{2}{*}{ Postest } & 36.09 & 5.67 & 0.97 & 1 \\
\hline & & 0 & 2 & \\
\hline \multicolumn{5}{|c|}{ Tindakan } \\
\hline \multirow[t]{2}{*}{ Pretest } & 20.68 & 3.41 & 0.56 & \\
\hline & & 8 & 8 & 0,00 \\
\hline \multirow[t]{2}{*}{ Postest } & 22.35 & 3.19 & 0.54 & 1 \\
\hline & & 0 & 7 & \\
\hline
\end{tabular}

perlakuan 13 orang $(38,2 \%)$ dan negatif 21 orang $(61,8 \%)$. Sedangkan memiliki sikap positif setelah perlakuan 22 orang $(64,7 \%)$ dan 12 orang $(35,3 \%)$ memiliki sikap negatif dan untuk variabel tindakan baik sebelum perlakuan 9 orang $(26,5 \%)$ dan negatif 25 orang $(73,5 \%)$ dan setelah perlakuan memiliki tindakan baik 20 orang $(58,8 \%)$ dan 14 orang $(41,2 \%)$ memiliki tindakan kurang baik.

Berdasarkan tabel 3 menunjukan penelitian ini dapat disimpulkan terjadi perubahan signifikan antara edukasi melalui media video dan leaflet terhadap perilaku personal hygiene pada masa menstruasi remaja dengan nilai $(\mathrm{p}$ $=0,000$ ) yang berarti Ho ditolak dan $\mathrm{Ha}$ diterima. Sedangkan sikap diperoleh nilai $(\mathrm{p}=0,001)$ yang berarti Ho ditolak dan Ha diterima dan tindakan diperoleh nilai $(\mathrm{p}=0,001)$ yang berarti Ho ditolak dan Ha diterima.

\section{DISKUSI}

Dalam penelitian ini penulis menganggap bahwa dengan adanya edukasi siswi lebih memahami bagaimana cara menjaga personal hygiene menstruasi dengan tingkat signifikan $<0,05$ di SMPN 2 Toili Berdasarkan angka tersebut dapat disimpulkan bahwa terjadi perubahan pemahaman pengetahuan, sikap 
maupun tindakan siswi ketika diberikan pemahaman bahwa pentingnya kebersihan diri pada saat menstruasi dan oleh karena itu diharapkan penelitian ini dapat dijadikan suatu pembelajaran bahwa personal hygiene membutuhkan kesadaran siswi pada saat menstruasi dan pada dasarnya sebelum diberikan intervensi leaflet dominan siswi berpengetahuan kurang baik namun setelah diberikan intevensi leaflet mengalami perubahan pengetahuan terbukti terjadi peningkatan sebanyak 13 orang siswi setelah diberikan intervensi berpengetahuan baik. Sedangkan pada variabel sikap dominan siswi memiliki sikap negatif. Akan tetapi setelah dilakukan intervensi terjadi peningkatan siswi yang memiliki sikap positif sebanyak 9 orang dan pada variabel tindakan dominan siswi memiliki tindakan kurang baik namun setelah dilakukan intervensi terjadi peningkatan sebanyak 11 orang memiliki tindakan baik.

Dari hasil penelitian menunjukkan bahwa variabel tindakan yang paling dominan mengalami perubahan setelah diberikan perlakuan. Hal ini sesuai dengan teori yang menyatakan bahwa tindakan merupakan bentuk perilaku manusia dalam melakukan segala sesuatunya yang menurut mereka harus dijalankan khususnya bagi siswi yang melakukan kebersihan diri pada saat menstruasi dan perlu dipahami bahwa ketika seorang siswi mampu melakukan tindakan yang baik pada saat menstruasi itu dilandasi oleh pengetahuan dan pemahaman dalam menyikapi masalah yang dialami saat menstruasi.

Hal ini karena dipengaruhi oleh pemahaman yang masih salah sehingga kemampuan untuk dipraktekan berada pada kondisi yang tidak benar dan pengalaman orang sekitar dimana melaksanakan personal hygiene menstruasi masih kurang atau tidak benar seperti mencuci organ kewanitaan dengan cairan pembersih vagina, tidak sering mengganti pembalut, cara membasuh organ genetalia eksternal yang dari belakang ke depan dan sebagainya, sehingga pengetahuan para siswi kurang lengkap dan hanya pada kategori kurang saja. Pengalaman pribadi ataupun orang lain dapat digunakan sebagai upaya memperoleh pengetahuan dengan cara mengulang kembali pengalaman pernah diperoleh dalam memecahkan permasalahan.

Sejalan dengan hal tersebut dalam dunia pendidikan kesehatan saat ini dasar tentang sistem reproduksi manusia harus diberikan. Karena dengan pengetahuan yang baik tentang menstruasi, remaja akan merasa tenang dan siap menghadapi dan mengatasi masalah yang terjadi saat menstruasi berlangsung. Jika ada peristiwa menstruasi yang tidak disertai dengan pengetahuan dan informasi yang benar, maka bisa timbul macam-macam problem psikis. Hal ini sesuai dengan teori yang menyebutkan bahwa semakin remaja putri terbuka dalam menggali informasi mengenai organ reproduksinya, maka akan semakin luas wawasan dan pemahaman mengenai kesehatan reproduksi. Jika menstruasi disertai dengan pengetahuan yang benar, remaja putri akan merespon menstruasi dengan hal-hal atau perilaku yang positif (15).

Hasil penelitian diatas sejalan dengan yang dilakukan oleh Mardawiah (2015) di SMP Negeri 27 Jakarta Selatan menunjukkan bahwa dari 58 orang yang dijadikan sebagai sampel, terdapat 36 orang yang berpengetahuan baik setelah diberikan edukasi melalui video dan leaflet dengan nilai ( $\mathrm{p}=$ 0,002), sebanyak 32 orang yang memiliki sikap positif setelah diberikan 
edukasi melalui video dan leaflet dengan nilai $(\mathrm{p}=0,018)$ dan tindakan baik sebanyak 37 orang setelah melihat video dan dibagikan leaflet dengan nilai $(\mathrm{p}=0,027)$. Dengan demikian pengetahuan, sikap dan tindakan memiliki pengaruh signifikan terhadap perilaku remaja mengenai edukasi personal hygiene saat menstruasi menggunakan video dan leaflet (10).

Peneliti telah berusaha semaksimal mungkin untuk mendapatkan kebenaran yang validmasi dan menyeluruh, namun demikian peneliti masih mengamati beberapa keterbatasan dalam penelitian ini diantaranya yaitu Pada proses pengambilan data penelitian yaitu penentuan waktu dan pembagian kuesioner, peneliti dibantu oleh 1 orang rekan atau guru namun demikian kemungkinan terjadi dalam pengisian kuesioner dikarenakan ada beberapa responden yang masih bertanya pada temannya karena merasa tidak yakin dan tidak percaya diri dengan jawabannya sendiri oleh karena itu ada beberapa pertanyaan yang kemungkinan dijawab dengan tidak jujur dan Responden terbatas dalam mengungkapkan jawaban secara objektif dan sebagian masih merasa malu dan tabu untuk membicarakan masalah personal hygiene saat menstruasi.

\section{UCAPAN TERIMAKASIH}

Peneliti sangat berterimaksih kepada responden, beserta kepala sekolah, dan staf yang ada di SMPN 2 Toili telah membantu dalam pengumpulan data, serta pembimbing yang senantiasa memberikan masukan sehingga penelitian ini dapat terlaksana.

\section{KESIMPULAN}

Adapun kesimpulan dari penelitian ini yaitu, Pengetahuan berpengaruh dan signifikan terhadap perilaku personal hygiene pada masa menstruasi remaja di SMPN 2 Toili Kec. Mailong kab. Banggai.

Sikap berpengaruh dan signifikan terhadap perilaku personal hygiene pada masa menstruasi remaja di SMPN 2 Toili Kec. Mailong kab. Banggai.

Tindakan berpengaruh dan signifikan terhadap perilaku personal hygiene pada masa menstruasi remaja di SMPN 2 Toili Kec. Mailong kab. Banggai.

Disarankan kepada pihak sekolah agar rajin melakukan penyuluhan dan mendatangkan tenaga kesehatan untuk memberikan materi mengenai personal hygiene pada masa menstruasi dan disarankan kepada remaja putri untuk menjaga personal hygiene dengan baik agar terhindar dari berbagai penyakit yang membahayakan organ reproduksi wanita.

\section{REFERENSI}

1. Sri, LN. Jurnal Pengaruh Pengetahuan Tentang Kesehatan Reproduksi Remaja Terhadap Perilaku Seksual Pranikah Remaja di Indonesia. 2012 ; (1):15-20

2. Katarina, CP. Jurnal personal hygiene Remaja Putri Ketika Menstruasi. 2017; (5):12-24.

3. Mariene. Jurnal Faktor Yang Berhubungan Dengan Praktek Hygiene Menstruasi Pada Siswi SMA Negeri 1 Sesean Kabupaten Tana Toraja. 2013; (2):3

4. Novianti. Jurnal Hubungan Pengetahuan, Sikap dan Tindakan Dengan Personal Hygiene Menstruasi Pada Remaja Putri di 
SMP Negeri Satap Bukit Asri Kabupaten Buton. 2016; (1):5-7

5. Siti, N. jurnal Analisa Determinan Pengetahuan dan Sikap Remaja Putri Tentang Dismenorhea. 2018;(1):5

6. Aulia, K. jurnal Hubungan Pengetahuan, Sikap dan Perilaku Personal Hygiene Dengan Gejala Vaginitis pada Siswi SMPN 1 Kota Padang dan SMPN 23 Padang. 2019; (1): 8

7. Cholisatul, Z. jurnal Pengaruh Edutainment Ular Tangga Terhadap Perilaku Remaja Tentang Personal Hygiene Menstruasi. 2018; (3):2.

8. Ita, TS. Jurnal Pengaruh Penyuluhan Tentang Menstruasi Terhadap Sikap Remaja Putri Pra Menstruasi. 2014; (1):1

9. Meinarisa. Jurnal Pengaruh Pendidikan Kesehatan Menstrual Hygiene (PMH) Terhadap Sikap Remaja Putri Dalam Menjaga Kebersihan Diri Selama Menstruasi. 2019;(4):1

10. Nyoman, S. jurnal Hubungan Antara Tingkat Pengetahuan Dengan Sikap Remaja Putri Terhadap Pentingnya Konsumsi Makanan yang Mengandung Zat Besi Saat Menstruasi di SMAN 2 Tabanan. 2013; (1):1-2

11. Dina, FY. Jurrnal Faktor Yang Berhubungan Dengan Praktik Menstrual Hygiene Genitalia Pada Siswi

Tunagrahita;2016;(1):1

12. Wanodya, P. Jurnal Pengaruh Media Booklet Terhadap Pengetahuan Dan Sikap Remaja Putri Terkait Kebersihan Dalam Menstruasi Di Pondok Pesantren Al-Ishlah Demak;2017;(1):2

13. Emmi, B. Jurnal Faktor Yang Berhubungan Dengan Personal Hygiene Selama Menstruasi Pada
Santriwati di Pesantren Babul Khaer Kabupaten Bulukumba. 2016;(1):2

14. Andri, SW. Jurnal Faktor Yang Berhubungan Dengan Personal Hygiene Saat Menstruasi.2018;(4):2

15. Mardawiah. Jurnal Faktor Yang Berhubungan Dengan Personal Hygiene Selama Menstruasi di SMP Negeri 27 Jakarta Selatan. 2015;(2):1

16. Abdullah, N. juarnal Kesehatan reproduksi. 2015; (3):4

17. Arianto. Jurnal Pengelompokan Remaja. 2015;(2):2-3

18. Hery, E. Jurnal Pengetahuan Kesehatan Reproduksi Remaja di Daerah Pedesaan. 2018;(1):4

19. Manuaba, Ida Bagus Gde. Jurnal Ilmu Kebidanan, Penyakit Kandungan dan KB. 2014;(2):6

20. Novitasari. Jurnal Menstruasi Pada Remaja. 2015;(2):1-2

21. Notoadmodjo. Jurnal Metodologi Penelitian Keseahatan. 2014;(1):2-3

22. Oswati, H. Jurnal Analisa Kesehatan Reproduksi Remaja Perempuan Usia Early Adolescence di Pekanbaru. 2013;(9):1-2

23. Prawirohardjo. Jurnal Ilmu Kebidanan Kesehatan Reproduksi. 2013;(2):1-2

24. Saifuddin. Jurnal Praktis Pelayanan Kontrasepsi ibu pertama kali menikah. 2016;(1):1-2

25. Sugihartono. Jurnal Psikologi Pendidikan dalam kesehatan reproduksi. 2015;(1):3-4 